Vol. 11 (3): 537-544 (2021)

\title{
PHYSICOCHEMICAL ANALYSIS OF THE WATER WELLS IN THE AREA OF RAHOVEC
}

\author{
Gani Kastrati ${ }^{1}$, Vjosa Morina ${ }^{2}$, Kreshnik Nuredini ${ }^{2}$, Betim Ismajli ${ }^{2}$, \\ Bahrije Dobra $^{2 *}$, Skender Demaku ${ }^{2 *}$ \\ ${ }^{1}$ University for Business and Technology, Calabria neighborhood, 10000 Pristine, Kosovo; \\ ${ }^{2 *}$ University of Prishtina "Hasan Prishtina", Faculty of Natural Science and Mathematics, \\ Department of Chemistry, str. "Nënë Tereze"nr.5, 10000 Prishtina, Kosovo; \\ "Corresponding Authors Bahrije Dobra, Skender Demaku, \\ e-mail: buki-d@ hotmail.com; skender.demaku@ hotmail.com;
}

Received March 2021; Accepted April 2021; Published June 2021;

DOI: $\underline{\text { https://doi.org/10.31407/ijees11.325 }}$

\begin{abstract}
In this paper, as our main goal, we had the analysis of heavy metals in the water and sludge of wells, in residential areas, and the land near these wells, in the villages: Vrajak, Ratkoc and Rogovë, in the area of Rahovec. Also, the physic-chemical parameters have been our goal in the study, to make the assessment of the current situation, taking into account the climatic factors, at the time when we did the analysis. Groundwater was characterized with high solubility of salts (high or medium hardness), in contrast to surface waters, especially those at high altitudes, where the amount of magnesium and calcium salts, is smaller. Thus, it is very important to assess the quality of water in wells used as drinking water sources by people living in these villages in the municipality of Rahovec. Sampling was done in the monthly period (August/2018). By using inductively coupled plasma optical emission spectroscopy (ICP-AES), the concentrations of 10 elements were determined in: water, sludge and soil samples (As, $\mathrm{Cd}, \mathrm{Co}, \mathrm{Cr}$, $\mathrm{Cu}, \mathrm{Fe}, \mathrm{Mn}, \mathrm{Ni}, \mathrm{Pb}$ and $\mathrm{Zn}$ ).
\end{abstract}

Keywords: Pollution, environment, villages, heavy metals, water, sludge, soil, ICP-AES technique. 